\title{
Determinant of Islamic Corporate Social Responsibility (ICSR) Disclosure in Companies Registered in Jakarta Islamic Index (JII)
}

\author{
Ainul Fatha Isman ${ }^{1)}$, Nur Cholifatul Aeni2) \\ 1) Universitas Islam Negeri Syarif Hidayatullah, Jakarta, Indonesia \\ 2)Badan Amil Zakat Nasional Kabupaten Gowa, Makassar, Indonesia \\ Corresponding author: ainulfathais@gmail.com
}

\begin{abstract}
:
Social aspects are important aspects that must be considered by every individual. Similarly, companies that must disclose social responsibility or what is called Corporate Social Responsibility (CSR) through the mandate of the Act. This research aims to determine the factors that affect the Islamic corporate social responsibility disclosure in Indonesia. This research is categorized in quantitative research with associative approaches. The population in this study amounted to 30 companies registered in the Jakarta Islamic Index in 2016-2018 with a purposive sampling technique to obtain 51 samples. The data analysis model in this study is a panel data linear regression test with a combination of time series data and crosssection which is carried out through three approaches, namely the common effect model, the fixed-effect model, and the random effect model. The results of this study indicate that partially and simultaneously the size of the company's profitability, and the Muslim board of directors influence the disclosure of the company's ICSR. The most influential factor in company ICSR disclosure is company size. The results of this study imply that each company uses the ISR Index as a reference for the preparation of sharia corporate social responsibility reporting standards and increases the number of Muslim board of directors who are competent and have innovative ideas to increase company assets, thus positively impacting ICSR disclosure.
\end{abstract}

Keywords: Company Size, Profitability, Muslim Board of Directors, Islamic Corporate Social Responsibility, Jakarta Islamic Index.

\section{Abstrak :}

Aspek sosial adalah aspek penting yang harus diperhatikan oleh setiap individu. Demikian pula dengan perusahaan yang harus mengungkapkan tanggung jawab sosial atau yang disebut Corporate Social Responsibility (CSR) melalui amanat Undang-Undang. Penelitian ini bertujuan untuk menganalisis faktor-faktor yang mempengaruhi pengungkapan tanggung jawab sosial perusahaan syariah di Indonesia. Penelitian ini dikategorikan dalam penelitian kuantitatif dengan pendekatan asosiatif. Populasi dalam penelitian ini berjumlah 30 perusahaan yang terdaftar dalam Jakarta Islamic Index pada tahun 2016-2018 dengan teknik purposive sampling yang berjumlah 51 sampel. Model analisis data dalam penelitian ini adalah uji regresi linear data panel dengan kombinasi time series dan cross-section yang dilakukan melalui tiga pendekatan, yaitu common effect model, the fixed-effect model, dan the random effect model. Hasil penelitian ini menunjukkan bahwa parsial dan simultan ukuran profitabilitas perusahaan, dan dewan direksi Muslim mempengaruhi pengungkapan ICSR perusahaan. Faktor yang paling berpengaruh dalam pengungkapan ICSR perusahaan adalah ukuran perusahaan. Hasil penelitian ini mengisyaratkan bahwa setiap perusahaan menggunakan Indeks ISR sebagai acuan penyusunan standar pelaporan tanggung jawab sosial perusahaan syariah dan meningkatkan jumlah direksi Muslim yang kompeten dan memiliki ide-ide inovatif untuk meningkatkan aset perusahaan, sehingga berdampak positif terhadap pengungkapan ICSR.

Kata Kunci: Ukuran Perusahaan, Profitabilitas, Dewan Direksi Muslim, Islamic Corporate Social Responsibility, Jakarta Islamic Index. 


\section{INTRODUCTION}

Corporate Social Responsibility (CSR) is a discourse that is emerging in the world of multinational companies. The Company is likened to a human being who has social and environmental responsibility in living his daily life. This value abstraction is then raised at the corporate level. ${ }^{1}$ Thus the company is faced with an obligation that must be fulfilled and implemented so that the company and the community can be guaranteed its existence and sustainability.

The development and motives of CSR as stated by Porter and Kromer that economic and social goals are separate and contradictory are wrong views. The company does not function separately from the surrounding community. The company's ability to compete is highly dependent on the local circumstances in which the company operates. ${ }^{2}$ Therefore, the pyramid of corporate responsibility must be understood as an integral part of its role in society. CSR in Indonesia is growing with the issuance of regulations on practice obligations and CSR disclosure through Law Number 40 of 2007. One of the mandates of the law is a report on the implementation of social and environmental responsibility. ${ }^{3}$

In principle, all companies in Indonesia use the Act as the basis for CSR disclosure. The concept of CSR is not only developing in conventional economics but also developing in Islamic economics. Nowadays there are many companies are implementing sharia principles in their business activities, which became known as Islamic Social Reporting (ISR). ISR is a standard of reporting on social performance of companies that conduct business activities with sharia principles and is submitted by the company in its annual report.

CSR in Islam is not a new thing. Because basically, CSR is a program with the company's social concern for the environment. Companies are not only pursuing profits but also a social responsibility to the community. There are many verses in the Qur'an that explain the need to pay attention to people around, namely the poor, the needy, slaves and others. Sharia-based companies also began to develop with the establishment of the Jakarta Islamic Index (JII) which consists of 30 sharia companies listed on the Indonesia Stock Exchange (IDX). The Islamic capital market is developing so fast that companies listed on JII are expected to present a religious dimension in CSR disclosure. So that it is required the standard of making social responsibility reports in meeting company obligations according to sharia. ${ }^{4}$ Over the years, companies registered with JII have carried out ICSR disclosures. The following graph is the disclosure of ICSR companies in the Jakarta Islamic Index (JII)In recent years, companies registered with JII have carried out ICSR disclosures. The following graph is the disclosure of ICSR companies in the Jakarta Islamic Index (JII):

Figure 1

Graph of ICSR Disclosure to JII Listed Companies in 2016-2018

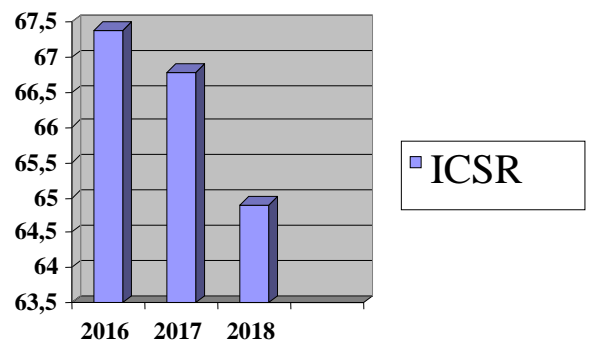

\footnotetext{
${ }^{1}$ G Widjaya, ) Resiko Hukum Dan Bisnis Perusahaan Tanpa CSR (Jakarta: Forum Sahabat, 2008).

${ }^{2}$ Suharto E, Pekerjaan Sosial Di Dunia Industri Memperkuat CSR (Bandung: Alfabeta, 2009).

${ }^{3}$ Waryanto, 'Effect of Characteristics of Good Corporate Governance (GCG) on the Disclosure of CSR in Indonesia', E Journal UNDIP, 7.4 (2010), 16-28.

${ }^{4}$ M.F.d.M Fitri, 'Factors That Influence CSR Disclosure to Companies Listed in the Jakarta Islamic Index 2012-2015', Malaysian Journal of Accounting Student Scientific Journal, 1.2 (2016), 21-30.
} 
The graph illustrates the level of disclosure of ICSR sharia companies registered in JII has decreased. In 2016 the ICSR disclosure rate was $67.4 \%$ and decreased the following year by $66.8 \%$. Up to 2018 , the level of ICSR disclosure continued to decline, reaching $64.9 \%$. In the disclosure of ICSR, the company is expected to be under the principles and ethics in Islam. Several factors are causing the decline in ICSR disclosure rates, such as company size, company age, profitability, public ownership, liquidity, type of industry, the etc. composition of the Muslim board of directors, and others.

Based on previous studies, this study wants to research other factors that can influence ICSR disclosures that have not been studied by M. Fajrul Novrizal and Meutia Fitri in 2016, namely adding another factor, the Muslim board of directors which is expected to influence the disclosure of Islamic Corporate Social Responsibility. In Pratama's research (2016) it did not have a significant effect on company size on the disclosure of Islamic Social Reporting. ${ }^{.}$In contrast to Majeed's research $(2015)^{6}$ which shows that company size has a positive effect on the level of disclosure of ICR while profitability is not a factor that affects the level of ICSR disclosure. Besides, the object of this research will use companies listed on the Jakarta Islamic Index with a different observation period than the previous research.

This research will discuss the factors that influence the disclosure of company ICSR by using independent variables namely company size, profitability, and Muslim board of directors. The larger the size of a company, the more information available to investors in the company's annual report. So companies that have greater total assets will have a higher level of ICSR disclosure than companies with smaller total assets. Based on data from 17 annual reports of companies listed on JII, several companies experience fluctuations in total assets that describe the size of a company, such as PT. Lippo Karacawi Tbk which experienced total assets hit by $24 \%$ in 2017 . However, decreased in the following year by $12 \%$ in $2018 .{ }^{7}$ One of the causes of these fluctuations is a trade war between the United States and China that has an impact on increasing interest rates in Indonesia and weakening people's purchasing power.

In addition to company size, a factor that can influence the level of ICSR disclosure is profitability. Companies that are in a profitable position will tend to disclose wider information in their annual reports. However, based on the company's annual report on JII, the average value of the company's profitability continued to decline from 2016 to 2018 amounting to $2.09 \%, 2.07 \%$, and $2.06 \%{ }^{8}$ Likewise, the composition of the board of directors as an organ that plays a role in corporate management decision making. The presence of Muslim board of directors in a company is an organ that is responsible for carrying out company policies that are in accordance with sharia, so that companies with a greater number of Muslim boards will tend to make disclosure more widely ICSR. However, based on the company's annual report data in JII, on average the composition of Muslim board of directors in the company stagnated by 3 people in 2017 and more worrying because it decreased in 2018 by 2 people. So that for company policy making according Sharia principles will be reduced and will have an impact on the level of ICSR disclosure.

Based on the description above that the company has an important role in the disclosure of ICSR as a form of social and environmental assistance to the community. But on the other hand, many factors can influence the disclosure of ICSR. Although there have been studies on the disclosure of ICSR, the factors used are different and similar studies have not examined the most recent period from 2016-2018. This is the reason the authors researched

\footnotetext{
${ }^{5}$ A. P Lestari, 'Pengaruh Corporate Governance Dan Profitabilitas Terhadap ISR Pada Bank Syariah' (Universitas Islam Indonesia, 2018).

${ }^{6}$ S Majeed, 'The Effect of Corporate Governance Elements on Corporate Social Responsibility (CSR) Disclosure', International Journal of Financial Studies, 2.2 (2015).

7 IDX, Annual Report, 2018.

8 IDX.
} 
the theme "Determinant of Disclosure of Islamic Corporate Social Responsibility (ICSR) on companies registered in the Jakarta Islamic Index (JII) 2016-2018".

\section{RESEARCH METHEDOLOGY}

This research uses a quantitative method with an associative approach. Quantitative research is a research method based on positivism, used to examine populations or certain samples by using data analysis tools that can be measured with the aim of testing research results. ${ }^{9}$ An associative approach to analyzing the level of influence of company size factors, profitability, and Muslim board of directors on the level of ICSR disclosure of companies listed on the Jakarta Islamic Index (JII).

This study uses secondary data which is time-susceptible data on an annual scale taken from the historical annual report of companies listed on the Jakarta Islamic Index (JII) on the Indonesian bursa effect. The data collection method used is the documentation method. Researchers obtained data from documents in the form of annual reports of companies listed on the Jakarta Islamic Index (JII) during the 2016-2018 period published by the Indonesia Stock Exchange. The population in this study are all companies that are also listed on the Jakarta Islamic Index. The sample selection in this study uses a purposive sampling method, namely the selection of samples based on an assessment of some of the characteristics of sample members to get samples following specified criteria and adjusted to the purpose of the study. ${ }^{10}$

Based on the sampling technique used, 17 companies that met the criteria of the researchers were obtained during the 2016-2018 period. Thus the number of samples in this study was 51 samples. The selection of the number of samples is based on several characteristics and sampling criteria. The following criteria and summary of the results of the sampling process conducted by researchers:

Table 1

Summary of sampling results

\begin{tabular}{|c|l|c|}
\hline Number & \multicolumn{1}{|c|}{ Criteria } & Amount \\
\hline 1. & Companies registered in JII for 3 periods in 2016-2018 & 30 \\
\hline 2. & Companies that are not listed on JII for 3 periods 2016-2018 & $(10)$ \\
\hline 3. & $\begin{array}{l}\text { Companies that do not use the Rupiah currency as a unit of } \\
\text { financial statement currency }\end{array}$ & $(3)$ \\
\hline 4. & Companies that do not make financial reports public & 0 \\
\hline 5. & $\begin{array}{l}\text { Companies that do not have complete data related to } \\
\text { research variables for 3 periods, 2016-2018 }\end{array}$ & 0 \\
\hline & Amount of companies & 17 \\
\hline & Amount of years of research & $\mathbf{3}$ \\
\hline & Total sample & $\mathbf{5 1}$ \\
\hline
\end{tabular}

The analysis technique used is descriptive statistical analysis techniques and panel data regression model analysis. Descriptive statistics are used to describe the variables of this study, namely company size, profitability, Muslim board of directors, and ICSR disclosures for JII companies in 2016-2018. While the panel data regression model analysis is a combination

\footnotetext{
${ }^{9}$ Sugiyono, Metode Penelitian Kombinasi (Jakarta: Alfabeta, 2017).

${ }^{10}$ M Kuncoro, Metode Riset Untuk Bisnis Dan Ekonomi (Jakarta: Erlangga, 2009).
} 
of time series data and cross-section conducted through three approaches, namely the common effect model, the fixed-effect model, and the random effect model.

To choose the most appropriate model used in processing panel data, several tests can be done, including Chow Test and Hausman Test. The hypothesis testing in this study uses panel data regression analysis which aims to predict how the state (ups and downs) of independent variables on the dependent variable. The equations to test the hypotheses used in this study are as follows:

ICSR $=\alpha+\beta_{1}$ Size $+\beta_{2}$ Profitability $+\beta_{3}$ MBD $+\varepsilon$

Informations

$$
\begin{array}{ll}
\mathrm{Y} & =\text { ICSR disclosure variable } \\
\alpha & =\text { Constant } \\
\text { Size } & =\text { Company Size } \\
\text { Profitab } & =\text { Profitability } \\
\text { MBD } & =\text { Muslim board of directors } \\
\beta_{123} \quad=\text { Partial regression coefficient } \\
\varepsilon \quad=\text { Error }
\end{array}
$$

Then to determine the effect of the independent variables with ICSR disclosure, the research hypothesis tests conducted on the variables with testing consisting of the coefficient of determination (r2), simultaneous test (f), and partial test ( $\mathrm{t}$ ).

\section{RESULT AND DISCUSSION}

\section{Islamic Corporate Social Responsibility Concept}

Corporate Social Responsibility is a concept carried out by a company to carry out social responsibility by carrying out various activities that can improve the welfare of the community such as maintaining public facilities, providing scholarships, giving donations to disadvantaged citizens and others. According to the World Business Council for Sustainable Development, CSR is an ongoing commitment by the business community to act ethically and contribute to the economic development of the local community or the wider community, together with an increase in the standard of living of its work and its entire family. ${ }^{11}$

In addition to being profit-oriented, the company is also responsible for social problems caused by operational activities carried out by the company with environmental management so that it is not only limited to the orientation of the company's financial performance. The definition of social responsibility in Law No.40 of 2007, namely, "Social and environmental responsibility is the company's commitment to participate in sustainable economic development in order to improve the quality of life and the environment that is beneficial, both for the company itself, the local community, and society in general".

CSR in an Islamic perspective is a business practice that has Islamic responsibilities. The company adheres to Islamic norms, which is a commitment to sincerity by maintaining social contracts in its operations. CSR in an Islamic perspective according to the Accounting and Auditing Organization for Islamic Financial Institutions (AAOIFI), namely activities undertaken by Islamic financial institutions to fulfill religious, economic, legal, ethical, and discretionary responsibilities as financial institutions for both individuals and industries. ${ }^{12}$

The desire to report CSR under Islamic principles and the increasing number of companies and banks carrying out their activities based on sharia principles is one of the

\footnotetext{
${ }^{11}$ N. Hadi, Corporate Social Responsibility (Yogyakarta: Graha Ilmu, 2011).

12 Tarmizi, 'Effect of Environmental Performance on Financial Corporate Performance with Corporate Social Responsibility Disclosure as Intervening Variables. Diponegoro Journal of Accounting', Diponegoro Journal of Accounting, 1.4 (2012), 12-24.
} 
reasons for the development of CSR under Islamic principles. The Islamic Social Reporting Index was first introduced by Haniffa, then developed by several subsequent researchers such as R. Othman, Azlan Md Thani, and Erlane K. Ghani by researching Islamic companies listed on Bursa Malaysia. According to Haniffa specifically, the ISR index is an extension of social reporting that includes public expectations not only about the role of companies in the economy but also the role of companies in a spiritual perspective. Besides, ISR also emphasizes social justice related to reporting on the environment, minority rights, and employes. ${ }^{13}$ The ISR index has two main objectives, namely as a form of accountability to Allah SWT and the community and to increase the transparency of business activities by providing information that is relevant and following needs of decision-makers. ${ }^{14}$

Research conducted by Othman et al develops ISR index disclosure items into six disclosure themes that must be disclosed by the company. The six items have sub-themes to clarify in detail what items should be disclosed differently, depending on the object of research used. The six items are funding and investment, products and services, employees, the community, the environment and corporate governance. ${ }^{15}$

The Jakarta Islamic Index (JII) is an index developed by the Indonesian stock exchange in collaboration with Danareksa Investment Management to respond to information needs related to Islamic investment. JII filters the listed stocks. The reference in the screening is the Sharia fatwa issued by the National Sharia Council (DSN). Based on this fatwa the Indonesian Stock Exchange (IDX) chooses issuers whose business units are by sharia.

The fundamental difference between the conventional index and the Islamic index is that the conventional index includes all shares listed on the stock exchange by ignoring the halal aspects of haram, as long as the listed issuer's shares are under applicable regulations. In contrast to Islam that pays attention to all aspects of it. This is based on DSN MUI Fatwa No. 20 regarding the dete

Several factors have an impact on increasing or decreasing ICSR disclosure in companies listed in JII. In this study, there are three factors that we want to know the effect on ICSR disclosure, namely company size, profitability, and Muslim board of directors. Company size is a measurement scale that reflects the size of the company in several ways, including total assets, total sales, market capitalization. Company size is divided into three categories, namely large companies, medium companies, and small companies Rohana's theory (2009) that larger companies will tend to disclose ISR. There are various proxies used to measure the level of company size such as total assets, number of employees, number of sales, and others ${ }^{16}$. Larger companies generally have more funding, facilities and human resources compared to smaller companies. Thus, larger companies will tend to have a higher level of disclosure of responsibility compared to smaller companies.

Profitability level illustrates the company's ability to obtain profits through all the capabilities of existing resources such as sales, cash, capital, number of employees, number of branch companies, and others. ${ }^{17}$ Profitability is identical to the company's economic performance. The higher the company's ability to generate profits that can be seen from the effectiveness of asset management, the value of the company will also be relatively increased

\footnotetext{
${ }^{13}$ Haniffa, 'Social Reporting Disclousure: An Islamic Perspektif. Indonesia Management and Perspektif', Business and Economic Journal, 2.1 (2002).

14 Fitri.

15 Othman, 'Islamic Social Reporting of Listed Companies In Malaysia', International Business and Economic Resarch Journal, 9.4 (2010), 29-37.

16 Suwito, 'Analisis Pengaruh Karakteristik Perusahaan Terhadap Tindakan Perataan Laba Yang Dilakukan Oleh Perusahaan Yang Terdaftar Di Bursa Efek Jakarta', in Simposium Nasional Akutansi VIIISolo (Solo: Simposium Nasional Akutansi VIII, 2015).

17 S. Harahap, Analisis Kritis Atas Laporan Keuangan (Jakarta: Raja Grafindo Persada, 2008).
} 
to encourage a greater flow of funds for social responsibility programs. ${ }^{18}$ By the theory of Chariri (2008) that the higher the profitability, the more extensive the company will be in disclosing information including information about Islamic social responsibility. Some indicators that can be used to measure the level of profitability are Gross Profit Margin (GPM), Operating Profit Margin (OPM), Net Profit Margin (NPM), Return On Asset (ROA), Return On Investment (ROI), Return On Equity (ROI) ), Earning Per Share (EPS), and Basic Earning Power (BEP). ${ }^{19}$

The board of directors is an organ that is useful for forming an obligation, prohibition, and sanctions that must be obeyed by every employee so that it can become a guideline for all employees in carrying out their work. The board of directors in a company will determine the policies or strategies that will be taken by the company in the short term and long term. Increasing the size of the board of directors will benefit the company because it creates a network with outsiders and ensures the availability of resources. ${ }^{20}$ The presence of the Muslim board of directors as a person who has responsibilities that must be carried out in carrying out all obligations under sharia principles. The greater number of Muslim councils will tend to make broader social responsibility disclosures.

\section{The influence of company size, profitability, and Muslim board of directors simultaneously on the ICSR Disclosure.}

The selection of the model is done in two stages, the first is the chow test and the second is the thirst test. A Chow test is performed to determine the best model between a common effect or fixed effect. While the thirst test is conducted to determine the best model between fixed effects or random effects. The chow test results are as follows:

Table 2

Chow Test Results

\begin{tabular}{|c|c|c|c|}
\hline Effect Test & Statistic & d.f & Prob \\
\hline Cross-section F & 17,40 & 16,31 & 0,000 \\
\hline $\begin{array}{c}\text { Cross-section Chi- } \\
\text { square }\end{array}$ & 117,34 & 16 & 0,000 \\
\hline
\end{tabular}

Based on the results of the chow test in table 2 that the probability value of the crosssection $\mathrm{F}$ is 0,000 which indicates that $0,000<0.05$, then the conclusion $\mathrm{H} 0$ is rejected, meaning that the best model is the fixed effect. The next step is to determine the best model between fixed effects and random effects through the Hausman test. The following are the results of the Hausman test:

Table 3

Hausman Test Result

\begin{tabular}{|c|c|c|c|}
\hline Test Summary & Chi-Sq. Statistic & Chi-sq. d.f & Prob \\
\hline $\begin{array}{c}\text { Cross-section } \\
\text { random }\end{array}$ & 17,673 & 3 & 0,0005 \\
\hline
\end{tabular}

Based on the results of the Hausman test in table 3 that the value of the random crosssection is 0.0005 which indicates that $0.0005<0.05$, then the conclusion is the best model is a

\footnotetext{
${ }^{18}$ R Marsuki, 'Value Relevant of Accounting Numbers: Determinants of Corporate Social Responsibility Disclosure of Islamic Banks in Malaysia', The Journal of Muamalat and Islamic Finance Research, 9.1 (2012), 9-18.

${ }^{19}$ Kasmir, Analisis Laporan Keuangan (Jakarta: Raja Grafindo Persada, 2014).

${ }^{20}$ Mulyadi, Auditing (Jakarta: Salemba, 2002).
} 
fixed effect. So in this study, the fixed-effect model was used. Based on panel data regression data, the following results are obtained:

Table 4

Results of Panel Data Regression with Various Models

\begin{tabular}{|c|c|c|c|c|c|c|}
\hline \multirow{2}{*}{$\begin{array}{c}\text { Variable } \\
\text { Model }\end{array}$} & \multicolumn{2}{|c|}{ Commom Effect } & \multicolumn{2}{c|}{ Fixed Effect } & \multicolumn{2}{c|}{ Random Effect } \\
\cline { 2 - 7 } & t- Statistic & Coefficient & t- Statistic & Coefficient & t- Statistic & Coefficient \\
\hline C & $-0,272$ & $-2,234$ & 0,824 & 16,181 & 2,085 & 19,644 \\
\hline Size & 2,359 & 0,006 & 0,007 & 4,870 & $-0,350$ & $-0,001$ \\
\hline Profitability & 3,297 & 7,248 & $-0,428$ & $-1,255$ & 9,003 & 2,397 \\
\hline BMD & 2,297 & 0,285 & 8,954 & 1,010 & 2,085 & 0,824 \\
\hline $\begin{array}{c}\text { Adj.R } \\
\text { Squared }\end{array}$ & \multicolumn{2}{|c|}{0,270} & \multicolumn{2}{c}{0,889} & \multicolumn{2}{c|}{0,554} \\
\hline F- Statistic & \multicolumn{2}{|c|}{7,187} & \multicolumn{2}{c|}{22,126} & \multicolumn{2}{c|}{0,000} \\
\hline $\begin{array}{c}\text { Prob (F- } \\
\text { Statistic) }\end{array}$ & \multicolumn{2}{|c|}{0,000} & \multicolumn{2}{c}{0,000} & \multicolumn{2}{c}{} \\
\hline
\end{tabular}

ICSR $=16,181+4,870$ Size $+-1,225$ Profitability $+1,010$ BDM + eit.

Table 4 is the result of panel data regression using the common effect, fixed effect, and random effect models. The next step is to choose the best model to use. The selection of the model is done in two stages, the first is the chow test and the second is the thirst test. A Chow test is performed to determine the best model between a common effect or fixed effect. While the thirst test is conducted to determine the best model between fixed effects or random effects.

Partial significance test (t-test) can be done by looking at the variable $t$ value of the variable and its probability value. In table 4 can be seen as the probability value and the statistical $t$ value of each independent variable used. In this study, a confidence level of $\alpha=$ $5 \%$ was used, with $\mathrm{df}(\mathrm{n}-\mathrm{k})=(51-3)=48$, then $\mathrm{t}$-table 2,010 was obtained.

Based on the regression output in table 4 it can be seen that the company size variable has a statistical $t$ value of 0.007 which is smaller than the $t$ table 2.010 . The probability value is 0.993 , which is greater than the alpha $(0.05)$. So it can be concluded that the company size variable has no significant effect on the company's ICSR disclosure in JII. The profitability variable has a statistical $t$ value of -0.442 , which is smaller than the t-table 2.010. The probability value is 0.671 greater than alpha (0.05). So it can be concluded that the variable Profitability does not significantly influence the ICSR disclosure variable. The variable of the Muslim board of directors has a statistical $t$ value of 8.954, which is greater than the $2.010 \mathrm{t}$ table. The probability value is 0,000 , smaller than alpha (0.05). So it can be concluded that the variable of the Muslim board of directors significantly influences the ICSR disclosure variable.

Simultaneous significance test can be performed by looking at the F-statistic probability value and the F-statistical value, as shown in table 7. In this study used a level of confidence $\alpha=5 \%$ with $\mathrm{n}=51$ and $\mathrm{k}=3$, then the F-table value of 2.798 was obtained. Table 4 shows that the value of prob. (F-statistics) of 0,000 , which is smaller than alpha (0.05). The F-statistic value is 22.126, which is greater than the F-table 2.798. So it can be concluded that all variables X (Size, Profitability, DDM) simultaneously affect the $\mathrm{Y}$ variable (ICSR disclosure).

Based on the regression results as listed in table 4, it is known that the coefficient of determination (Adjusted R-squared) of 0.889 . This shows that the variation of the dependent variable (ICSR disclosure) can simultaneously be explained by the independent variable (Size, Profitability, DDM) of $88.9 \%$ while the remaining $11.1 \%$ is explained by other factors outside the studied variables. 


\section{a. Effect of company size on ICSR Disclosures}

The results of this study indicate that the size of the company does not significantly influence the level of 5\% with a probability value of 0.993 and is positively related to the coefficient value of 4.870 which means that if the size of the company rises by 1 (one) then the disclosure of ICSR in JII will increase by 4.870 .

The results of this study are consistent with the results of Saputra and Prasetyoningrum's research which revealed that the increase in company assets shows an increase in the size of the company and creates risk for increased costs, given the emergence of unemployed assets. The existence of assets that are unemployed forces them to spend more costs, there by reducing costs for social responsibility.

Companies registered at JII from 2016 to 2018 have disclosed ICSR information well, although it has not been maximized, which means that the company is trying to imply that the company has implemented sharia principles. Besides, one of the criteria for selecting the Islamic stock index in JII is based on the average order of the largest market capitalization for one year. Therefore, companies listed in JII should have a higher level of ICSR disclosure than companies not listed on JII.

\section{b. Effect of Profitability on ICSR disclosures}

The results of this study indicate that profitability does not significantly influence the level of $5 \%$ with a probability value of 0.671 and negatively related to the coefficient value 1,255 which means that if the size of the company rises by 1 (one) then the disclosure of ICSR in JII will decrease by $-1,255$.

The results of this study are consistent with the results of research conducted by Marsuki, Novrizal, and Majeed who stated that in the Islamic view of companies that have the intention to make disclosures will not consider whether the company is profitable or loss and continue to disclose ICSR information regardless of high or low profit owned so that profitability is not a factor that can influence companies to determine ICSR disclosures.

Companies with high profitability make management have the freedom and ease to express social responsibility. Based on data collected from annual reports of companies listed on JII during 2016-2018, the company's profitability tended to decrease due to uncertain global economic and financial conditions, thus impacting on ICSR disclosures which also declined.

\section{c. Influence of Muslim Board of Directors on ICSR Disclosure.}

The results of this study indicate that the Muslim board of directors has a significant influence on the level of $5 \%$ with a probability value of 0,000 and negatively associated with a coefficient value of 1.010 which means that if the size of the company rises by 1 (one) then the disclosure of ICSRs in JII will increase by 1.010.

The results of this study are consistent with research conducted by Othman and Majeed who stated that the composition of the Muslim board of directors had a positive and significant influence on the level of ICSR disclosure.

Based on data that has been processed that from the profile of the board of directors in the annual report of companies listed on JII during 2016-2018 the number of members of the board of directors is still very low. The lack of members of the board of directors who are Muslim in JII-listed companies is quite alarming to see that the majority of Indonesia's population is Muslim. There are still some companies that do not have any Muslim board of directors for a certain period. Whereas the presence of the board of directors serves to determine the goals and principles of the company's strategy, so companies with a greater number of Muslim board of directors will tend to make extensive disclosure on the ICSR. 
d. The influence of company size, profitability, and Muslim board of directors simultaneously on the ICSR Disclosure.

Based on the F test (simultaneous) in the regression model shows that the variables of company size, profitability, and Muslim board of directors simultaneously have a positive and significant effect on the level of Islamic Corporate Social Responsibility (ICSR) on companies registered in JII in 2016-21018.

In general, CSR is an effort to improve the company's image which will then have an impact on improving financial performance, where investors tend to invest capital in companies that carry out CSR activities because they see that companies that carry out CSR have the potential to generate greater profits. In the view of Islam, particularly sharia-based companies the purpose of the existence of CSR is more than just financial things but also in the formation of justice through social responsibility. So it is very important to pay attention to aspects that affect the level of ICSR disclosure.

It was also found that the coefficient of determination was 0.889 , which means the combination of company size, profitability, and Muslim board of directors influence the ICSR disclosure rate of $88.9 \%$ while the remaining $11.1 \%$ was influenced by other variables such as liquidity, industry type, environmental work, company age, leverage outside this regression model.

\section{CONCLUSIONS}

Based on the results of research and discussion that has been presented, it can be concluded that company size and profitability do not significantly influence the level of ICSR disclosure while the Muslim board of directors significantly influences the level of ICSR disclosure. But simultaneously, the three dependent variables influence the ICSR disclosure. The Muslim board of directors is the most influential variable on the level of ICSR disclosure.

Suggestions from the authors as a form of implications of the results of this study so that each company uses the ISR Index as a reference for making sharia corporate social responsibility reporting standards and in order to increase the number of Muslim board of directors who are competent and have innovative ideas in order to increase company assets, thus positively impacting ICSR disclosure. .

\section{REFERENCES}

E, Suharto, Pekerjaan Sosial Di Dunia Industri Memperkuat CSR (Bandung: Alfabeta, 2009)

Fitri, M.F.d.M, 'Factors That Influence CSR Disclosure to Companies Listed in the Jakarta Islamic Index 2012-2015', Malaysian Journal of Accounting Student Scientific Journal, 1.2 (2016), 21-30

Hadi, N., Corporate Social Responsibility (Yogyakarta: Graha Ilmu, 2011)

Haniffa, 'Social Reporting Disclousure: An Islamic Perspektif. Indonesia Management and Perspektif', Business and Economic Journal, 2.1 (2002)

Harahap, S., Analisis Kritis Atas Laporan Keuangan (Jakarta: Raja Grafindo Persada, 2008)

IDX, Annual Report, 2018

Kasmir, Analisis Laporan Keuangan (Jakarta: Raja Grafindo Persada, 2014)

Kuncoro, M, Metode Riset Untuk Bisnis Dan Ekonomi (Jakarta: Erlangga, 2009)

Lestari, A. P, 'Pengaruh Corporate Governance Dan Profitabilitas Terhadap ISR Pada Bank Syariah' (Universitas Islam Indonesia, 2018)

Majeed, S, 'The Effect of Corporate Governance Elements on Corporate Social Responsibility (CSR) Disclosure', International Journal of Financial Studies, 2.2 (2015)

Marsuki, R, 'Value Relevant of Accounting Numbers: Determinants of Corporate Social Responsibility Disclosure of Islamic Banks in Malaysia', The Journal of Muamalat and Islamic Finance Research, 9.1 (2012), 9-18

Mulyadi, Auditing (Jakarta: Salemba, 2002) 
Othman, 'Islamic Social Reporting of Listed Companies In Malaysia', International Business and Economic Resarch Journal, 9.4 (2010), 29-37

Sugiyono, Metode Penelitian Kombinasi (Jakarta: Alfabeta, 2017)

Suwito, 'Analisis Pengaruh Karakteristik Perusahaan Terhadap Tindakan Perataan Laba Yang Dilakukan Oleh Perusahaan Yang Terdaftar Di Bursa Efek Jakarta', in Simposium Nasional Akutansi VIIISolo (Solo: Simposium Nasional Akutansi VIII, 2015)

Tarmizi, 'Effect of Environmental Performance on Financial Corporate Performance with Corporate Social Responsibility Disclosure as Intervening Variables. Diponegoro Journal of Accounting', Diponegoro Journal of Accounting, 1.4 (2012), 12-24

Waryanto, 'Effect of Characteristics of Good Corporate Governance (GCG) on the Disclosure of CSR in Indonesia', E Journal UNDIP, 7.4 (2010), 16-28

Widjaya, G, ) Resiko Hukum Dan Bisnis Perusahaan Tanpa CSR (Jakarta: Forum Sahabat, 2008) 